I/330 of a horse-power!" Our author would surely have thought twice before writing "the distance from London to York is 200 miles per hour." But this, to which we invite his careful attention, would have involved no greater blunder.

"If the bodies are elastic . . ., the whole of the energy of the striking body is expended in producing motion in the body struck." After this it will not, perhaps, surprise the reader to find that we are furnished with a calculation of " the total heat from absolute zero resident in exploded powder, at an atmospheric temperature of $50^{\circ}$, or $510^{\circ}$ absolute."

The work may be made, even as a whole, thoroughly useful to those habituated to the persistent inaccuracies of the "vernacular":--but, to effect this, it must be carefully purged of statements analogous to the three last-made quotations.

P. G. T.

A FIELD NATURALIST IN EASTERN BENGAL Letters on Sport in Eastern Bengal. By Frank B. Simson, Bengal Civil Service, retired. (London: R. H. Porter, I886.)

TH HIS book is essentially a record of sporting scenes, and the author has ostensibly written it for the purpose of giving instruction in the art of shooting and hunting wild birds and beasts of various kinds, from quail and snipe to tigers and rhinoceroses. Yet it contains so many good observations on the haunts and habits of wild animals, and the author shows himself so capable a field naturalist, that a reader who looks for zoological information will probably be disappointed at not finding more novelty. The scene of Mr. Simson's principal adventures, Eastern Bengal, a vast plain traversed by mighty rivers, a country of rice fields and cane brakes, and great grass jungles, of " bheels," or marshes, and "churs," or temporary islands and sand-banks in rivers, has by no means been rendered too familiar by description. Fertile and peaceable, with never-failing rains and magnificent water communication, it furnishes few sensational paragraphs for newspaper correspondents or other manufacturers of periodical literature. The region is as little known to Anglo-Indians in general as the Highlands of Central India, so vividly described by Forsyth, or the wild Mysore country, of which the elephants, tigers, and other wild beasts found an historian in Sanderson. Why is it that the additions to our zoological knowledge made by $\mathrm{Mr}$. Simson are so much less important than those made by Sanderson and Forsyth?

The explanation is probably twofold, if not threefold. All the three writers named were enthusiastic sportsmen and good observers, but Forsyth and Sanderson related events of more recent date, the details of which were naturally more vivid, whilst the present work is a series of reminiscences, written out long after the incidents described took place. The avocations of the different writers, too, were very dissimilar. Those of the two authors first named led them to pass weeks and months amongst the haunts of wild animals, whilst Mr. Simson, a Bengal civilian, could only spend an occasional holiday at a distance from his office, or avail himself of a few hours at a time during the cold season's tour. Another reason, perhaps of even more importance, is the great difference in the nature of the country, and the different system of hunting rendered necessary. The great grasses of the Gangetic plain, even when reduced to patches by the fires of the spring, conceal the movements of their inhabitants, from rhinoceroses and buffaloes downwards, far more than do the jungles of Central and Southern India, especially after their much less luxuriant grasses have been burnt. The process of beating out a patch of thick grass io to 20 feet high with a lline of elephants differs widely in the opportunities afforded for observation, from the tracking, chiefly on foot, of the animal sought after, through the burnt glades of the Satpura hills or the comparatively thin undergrowth of the Sahyadri forests.

It must not be supposed that Mr. Simson's work contains no novel observations. A very large proportion of our acquaintance with the habits of animals, especially of the larger Mammalia, is due to sportsmen, but the value of their observations varies. A few sportsmen are deliberately untruthful,- - these are easily detected; but many more are unqualified for accurate observation. There is no better test of a writer's truthfulness and capacity than his snake stories. In America it is commonly said that there is no subject on which ordinary mortals are so prone to what may euphemistically be termed "romancing." Indian experience corresponds to American, and whatever may be the deficiencies of the Bengali peasant, no one ever credited him with want of imaginative power. The Europeans in India, as a rule, know nothing about snakes. In the work under review, two of the best letters (the whole is written in epistolary form) deal with snakes, and the account of the poisonous species, all of which are correctly named and described, is excellent. To have picked out the grains of truth, and disregarded the chaff, shows judicial acumen worthy of one who has, in the administration of the law, had much experience of conflicting evidence. One of the most interesting facts mentioned is the use made of cobra venom in poisoning arrows used for the destruction of wild animals.

Another interesting observation may be noted: the shooting of a tiger "whose paunch was crammed full of grasshoppers or locusts." Hitherto, although tigers were not thought to be very particular, they were supposed to draw a line at frogs, and were not suspected of condescending to devour insects.

The plates are good on the whole, the elephants excellent, and the lithograph entitled "A scrimmage with a tiger," is one of the best representations of the animals and men depicted to be found in any Indian sporting work. But the pigs-with one exception, in which the animal looks as if he had been shaved-are far too shaggy, and resemble the European boar, Sus scrofa rather than the Indian $S$. cristatus.

W. T. B.

\section{THE MEASURE OF THE METRE}

La Mésure du Mètre. By W. de Fonvielle. (Paris: Hachette, I886.)

M DE FONVIELLE'S little volume is truly national. 1. From one end to the other it rings with applause for those brave men of France who, in 1792 and the 